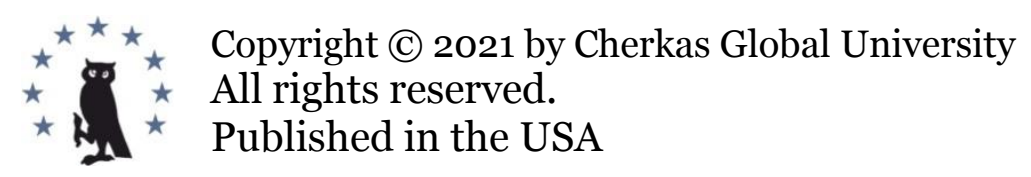

European Journal of Contemporary Education E-ISSN 2305-6746

2021. 10(4): 1042-1047

DOI: $10.13187 /$ jced.2021.4.1042

https://ejce.cherkasgu.press

IMPORTANT NOTICE! Any copying, reproduction, distribution, republication (in whole or in part), or otherwise commercial use of this work in violation of the author(s) rights will be prosecuted in accordance with international law. The use of hyperlinks to the work will not be considered copyright infringement.

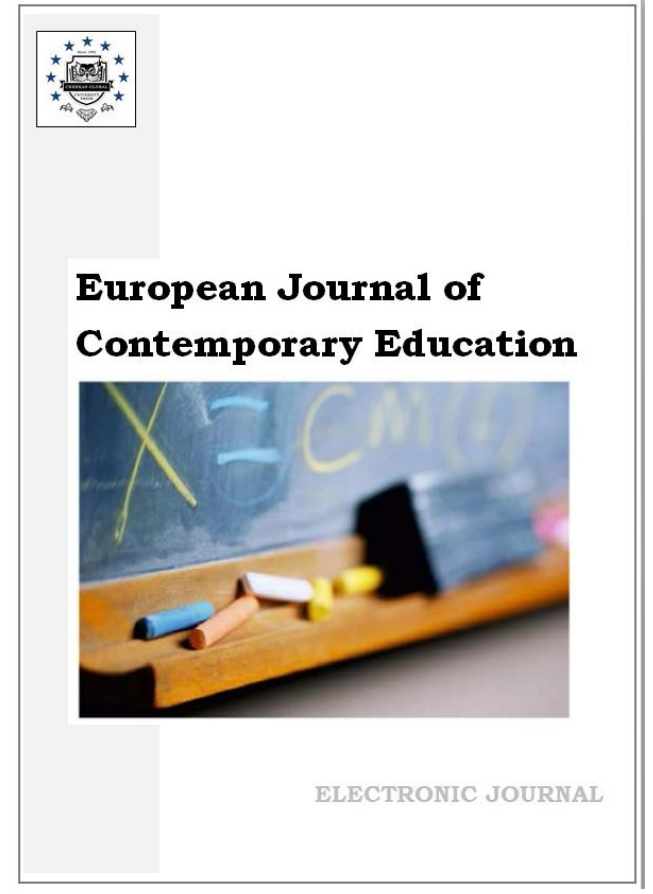

\title{
The History of Education
}

\section{The System of Public Education in Elisabethpol Governorate in the Period 1868-1917. Part 1}

Timur A. Magsumov a, b, c, *, Teymur E. Zulfugarzade ${ }^{d}$, Mikhail B. Kolotkov e, Sergei B. Zinkovskii ${ }^{\mathrm{f}}$

${ }^{a}$ Cherkas Global University, Washington, DC, USA

b Volgograd State University, Volgograd, Russian Federation

c Naberezhnye Chelny State Pedagogical University, Naberezhnye Chelny, Russian Federation

${ }^{\mathrm{d}}$ Russian Economic University named after G.V. Plekhanov, Moscow, Russian Federation

e Peter the Great St. Petersburg Polytechnic University, St.Petersburg, Russian Federation

f Peoples' Friendship University of Russia (RUDN University), Moscow, Russian Federation

This work investigates the system of public education in Elisabethpol Governorate in the period 1868-1917. The present part of the work examines the timeframe from 1868, i.e. the year the governorate was established, to 1884. A key source used in putting this work together is reports from the Trustee of the Caucasus Educational District for the period 1884-1914. The authors researched the reports for statistical data on the following: the types of the region's educational institutions, the number of schools in the region, its library holdings, and its student body (information related to student demographics, including ethnicity, religion, social estate, and gender). The use of the statistical method helped identify some of the key distinctive characteristics of the development of public education system in Elisabethpol Governorate in the period 18681884. The authors' conclusion is that by 1884, the system of public education in Elisabethpol Governorate was still in its incipience. Given the region's idiosyncrasies, girls had access to primary education only. The total number of educational institutions in the region was 39, with 2 of these being secondary, 4 - lower, and 33 - primary schools. The region had just two primary schools for girls. Its two other primary educational institutions were mixed schools. The rest of the region's educational institutions were for boys only. The total number of students in the region at the time was 2,789 -

\footnotetext{
${ }^{*}$ Corresponding author

E-mail addresses: nabonid1@yandex.ru (T.A. Magsumov)
} 
2,492 boys and 297 girls. Over 57\% of the student body was made up of Armenians (1,606 students), followed by Tatars - $23 \%$, Europeans $-13.8 \%$, and ethnic Russians - less than $5 \%$.

Keywords: Elisabethpol Governorate, Caucasus Educational District, period 1868-1917, history of pedagogy.

\section{Introduction}

Elisabethpol Governorate was formed on February 19, 1868, from several uyezds in the Tiflis and Baku governorates. Its capital was Elisabethpol. By the start of the $20^{\text {th }}$ century, the governorate consisted of 8 uyezds, 3 cities, and over 1,500 other settlements. It was one of the largest governorates in the Caucasus $\left(44,136 \mathrm{~km}^{2}\right)$. The governorate was formed from the Ganja, Karabakh, and Shaki khanates and the Samukh and Shamshadil mahals. Based on data for 1897, the majority of the region's population was made up of settled residents, with semi-nomads constituting its minority (a portion of the Tatars and Kurds). The region's settled residents were primarily engaged in crop farming, while their semi-nomadic counterparts mainly practiced animal husbandry. In 1897, the governorate had a population of 878,415 . Urban residents accounted for $10.1 \%$ and rural residents for $89.9 \%$ of its population (Pervaya vserossiiskaya perepis'..., 1904: III-IV).

In terms of its ethnic profile, the available census materials provide some information on the languages spoken in the region. Specifically, Tatar was spoken by $60.8 \%$ of the population, Armenian $-33.2 \%$, Lezgin $-2.5 \%$, Russian $-1.61 \%$, and German - $0.36 \%$. The figures for the rest of the region's ethnicities are too negligible to mention (Pervaya vserossiiskaya perepis'..., 1904: V). Thus, the Tatars and Armenians formed the largest ethnic groups in Elisabethpol Governorate. This composition of its population could not but have an effect on the development of the region's system of public education.

\section{Materials and methods}

A key source used in putting this work together is reports from the Trustee of the Caucasus Educational District for the period 1884-1914. Of principal significance for the present study is the earliest report for 1884, published in 1885 in Tiflis (Otchet, 1885). The reports carried statistical information on the numbers of educational institutions, students and teachers, books in the libraries, etc.

Wide use was made of the statistical method. The authors researched the reports for statistical data on the following: the types of the region's educational institutions, the number of schools in the region, its library holdings, and its student body (information related to student demographics, including ethnicity, religion, social estate, and gender). The use of the statistical method helped identify some of the key distinctive characteristics of the development of the system of public education in Elisabethpol Governorate in the period 1868-1884.

\section{Discussion}

Up to now, the system of public education in Elisabethpol Governorate in the period 18681917 has not been the subject of independent research. Existing research is limited to a few local studies works covering specific educational institutions in the region. An idea of the system of public education in this governorate can be obtained from a set of summarizing works on other regions of the Caucasus. Specifically, the system of public education in the Caucasus (Elisabethpol Governorate as part of the Caucasus Educational District) has been investigated by T.A. Magsumov (public education in Kars Oblast) (Magsumov et al., 2020; Magsumov et al., 2020a) and A.M. Mamadaliev (Tiflis Governorate) (Mamadaliev et al., 2020; Mamadaliev et al., 2020a; Mamadaliev et al., 2020b; Mamadaliev et al., 2020c).

When it comes to existing research concerning the education system in the Caucasus as a whole, a particular mention is due to O.V. Natolochnaya, who has investigated many of its different aspects (Natolochnaya et al., 2018).

In recent years, researchers have expressed keen interest in the study of the system of public education in various governorates within the Russian Empire. For instance, A.Yu. Peretyat'ko has researched a similar subject in the context of the Don region (Peretyatko, Zulfugarzade, 2017; Peretyatko, Zulfugarzade, 2017a; Peretyatko, Zulfugarzade, 2019; Peretyatko, Zulfugarzade, 2019a), O.V. Natolochnaya has explored the system of public education in Vilna Governorate (Natolochnaya et al., 2019; Natolochnaya et al., 2019a; Natolochnaya et al., 2020), and 
T.A. Magsumov has investigated the characteristics of the system of public education in Vyatka Governorate (Magsumov et al., 2018).

While there is a body of research carried out on the system of public education in the Caucasus and the Russian Empire as a whole, the system of public education in Elisabethpol Governorate remains underresearched. The purpose of the present study is to fill this gap.

\section{Results}

The network of educational institutions in the Caucasus, as across the Russian Empire as a whole, was divided into the systems of secondary, lower, and primary education.

\section{Secondary education}

The first male progymnasium in Elisabethpol Governorate was formed in 1870 as a result of the reorganization of Elisabethpol Uyezd School. On March 31, 1881, the progymnasium was reorganized into Elisabethpol Male Gymnasium (Otchet, 1885: tables), becoming the first secondary educational institution in the governorate.

In 1884, the male gymnasium was attended by 268 students. The largest portion of its student body was made up of children of nobles - 112 (as used herein, the term 'nobles' means personal nobles and hereditary nobles), followed by children of members of the urban estates 106, and then children of persons of ecclesiastical status - 32 students (Otchet, 1885: tables). Ethnically, 179 of these students were Armenians, 48 - Tatars, 30 - ethnic Russians, 5 - Georgians, and 5 - Europeans (Otchet, 1885: tables).

By 1884, Elisabethpol Male Gymnasium had the following library stock: 2,741 items in the fundamental library section and 813 items in the discipular one (Otchet, 1885: tables).

Another secondary educational institution in the governorate was Shusha Real School, established in the city of Shusha on October 20, 1881. Similar to the region's first male gymnasium, the real school was formed as a result of the reorganization of an urban two-grade school. In 1884, the real school was attended by 260 students. Similar to Elisabethpol Male Gymnasium, the majority of the student body were children of nobles (140), followed by children of members of the urban estates (104), and then children of persons of ecclesiastical status (9). The rest were children of members of other estates. The school had a similar situation in terms of the ethnic composition of its student body as well: 160 Armenians, 89 Tatars, 6 ethnic Russians, and 5 Georgians (Otchet, 1885: tables).

In 1884, Shusha Real School had the following library stock: 1,608 items in the fundamental library section and 374 items in the discipular one (Otchet, 1885: tables).

There were no female secondary educational institutions in the region at the time.

Thus, the governorate had just two secondary educational institutions, both for boys, with a combined enrollment of 528 students. Nearly half of these students were children of nobles (252), with the other half made up of children of members of the urban estates (210) and children of persons of ecclesiastical status (41). Ethnically, 65\% of students attending the region's secondary educational institutions were Armenians, 26\% - Tatars, with the remaining 9\% divided among ethnic Russians, Georgians, and Europeans. The region's secondary educational institutions did not have a large combined library stock in 1884 , the reason being the relative recency of their establishment.

\section{Lower education}

The first lower educational institution in Elisabethpol Governorate, Shusha Urban School, was opened on June 1, 1875. Subsequently, lower schools were opened in Nukha and Elisabethpol.

Thus, by 1884 the governorate had 3 urban schools: Elisabethpol School (est. on September 1, 1884)*, Shusha School (est. on June 1, 1875), and Nukha School (est. in 1877) (Otchet, 1885: tables).

In 1884, the very first year of its operation, Elisabethpol School enrolled 260, Shusha School - 296, and Nukha School - 203* students. In terms of the schools' estate composition, all three

\footnotetext{
* The school was established following an increase in demand for attending school in the capital subsequent to the opening of a male gymnasium in it.
} 
were dominated by children of members of the urban estates (Elisabethpol School - 153, Shusha School - 154, and Nukha School - 102 students). In Elisabethpol School and Shusha School, this group was followed by children of members of the rural estates (44 and 70, respectively) and then children of nobles ( 36 and 45 , respectively), whereas in Nukha School it was followed by children of nobles (50) and then children of persons of ecclesiastical status (33) (Otchet, 1885: tables). In terms of the schools' ethnic composition, the overwhelmingly largest group were Armenians (220, 257, and 146, respectively), followed by Tatars (33, 32, and 53, respectively), and then ethnic Russians and Georgians (7, 5, and 4, respectively). In addition, Shusha Urban School was attended by two children of Europeans (Otchet, 1885: tables).

Given the relative recency of the establishment of Elisabethpol Urban School, its library stock was not very big - just 92 items in the fundamental library section. Shusha School had a library stock of 1,706 items in the fundamental library section and 361 items in the discipular one. Nukha School had 1,841 items in the fundamental library section and 421 items in the discipular one (Otchet, 1885: tables).

Besides the urban schools, the governorate had one tradesman's school, Elisabethpol Tradesman's School, which was established on November 8, 1884. In the very first year of its operation, the tradesman's school enrolled 42 students. The bulk of the student body were children of members of the urban (23) and rural (13) estates, with the rest of the estates represented much less (nobles - 3, clergy - 2, and children of members of the lower ranks - 1) (Otchet, 1885: tables). Ethnically, there were 29 Armenians, 12 Tatars, and 1 ethnic Russian (Otchet, 1885: tables).

Given the recency of its establishment, the school's library only had books in its fundamental section - 125 items (Otchet, 1885: tables).

Thus, the region's four lower educational institutions had a combined enrollment of 801 students. More than half of them were children of members of the urban estates 4,332 students, or $54 \%$, followed by children of members of the rural estates - 145 students, or $18 \%$. There was a large group of children of nobles and functionaries as well -134 students, or $16.7 \%$. This group was followed by children of persons of ecclesiastical status $-11 \%$, with children of members of the lower ranks and foreigners bringing up the rear. In terms of the lower schools' ethnic composition, 81.5 \% (652) were Armenians, $16.25 \%$ (130) - Tatars, and just $2.25 \%$ (19) ethnic Russians, Georgians, and foreigners. The combined library stock in 1884 was 4,546 items, or 1,136 items per school. The region's lower educational institutions did not admit girls at the time.

\section{Primary education}

In 1884, the governorate had 25 schools (Otchet, 1885: tables): 3 publicly funded rural schools, 18 rural schools under the purview of the Ministry of Public Education, 1 rural primary school, 1 school run by a benevolent society, and 2 Lutheran parish schools. Of these, 8 were twograde, 17 were one-grade, 22 were male, 1 was female, and 2 were mixed schools (Otchet, 1885: tables).

Nine of the region's primary schools were opened in a 1-year period, 7 - in a 2-year period, $3^{-}$in 3-,4-, and 6-year periods, respectively, 3 - in an 8-year period, and just 3 - in a period of over 10 years. Thus, roughly an average of just four primary schools opened in Elisabethpol Governorate each year (Otchet, 1885: tables).

In 1884, Elisabethpol Governorate had a population of 593,000, which means there was on average one school per 23,700 people in the region. For instance, at that time Kuban Oblast had a population of around 1,000,000 and 268 schools, i.e. one school per 3,900 residents. Across the Caucasus as a whole, areas dominated by ethnic Russians had one school per even 3,500 residents, those dominated by Armenians - one school per 19,600 residents, and areas dominated by Tatars and mountaineers - one school per 45,400 residents (Otchet, 1885: tables). However, despite these statistics, there were regions where there was one school per 62,000 residents (e.g., Dagestan Oblast) (Otchet, 1885: tables).

Regarding the region's primary school buildings, out of its 25 schools, 24 had comfortable buildings and just 1 was housed in a building not intended for school purposes (Otchet, 1885: tables). In this respect, Elisabethpol Governorate rated in the top in the Caucasus Educational District.

\footnotetext{
${ }^{*}$ Note that Shusha School and Nukha School each had a much larger student body in 1883 (332 and 250 students, respectively) (Otchet, 1885: tables).
} 
In addition to core courses, the schools taught electives as well. Specifically, 22 of the region's primary schools taught singing, 23 - gymnastics, 1 - sewing, and 1 - bookbinding (Otchet, 1885: tables).

In 1884, the region's primary schools had a combined enrollment of 1,162 students 915 boys and 247 girls (Otchet, 1885: tables). The overwhelming majority of these students were children of members of the rural estates (923), followed by children of nobles and functionaries (119), children of persons of ecclesiastical status (61), children of members of the urban estates (57), and children of members of the lower ranks (2) (Otchet, 1885: tables). Ethnically, the way was led by Tatars (380), ahead, by a tiny margin, of Lutheran Europeans (379), followed by Armenians (317), ethnic Russians (85), and Georgians (1) (Otchet, 1885: tables).

In addition, in 1884 the governorate had 8 private primary schools (7 male and 1 female) (Otchet, 1885: tables), with a combined enrollment of 298 students (248 boys and 50 girls) (Otchet, 1885: tables). Estate-wise, the student body was made up of 229 children of members of the urban estates, 46 children of persons of ecclesiastical status, 15 children of nobles, and 8 children of members of the rural estates (Otchet, 1885: tables). Surprisingly, all of the students in private primary schools in the region were Armenians (Otchet, 1885: tables). The essential difference between private primary schools and other primary schools in the region is that all of the former were located in cities, i.e. none were located in rural areas.

Overall, the region's primary schools had a combined enrollment of 1,460 students, with 297 of these being girls. Children of members of the rural estates accounted for $63.7 \%$, followed by children of members of the urban estates $-19.5 \%$, children of nobles and functionaries $-9.1 \%$, and children of persons of ecclesiastical status $-7.3 \%$. Ethnically, $42.1 \%$ of all students in primary schools in the region were Armenians, $26 \%$ - Tatars, $26 \%$ - Europeans, and $5.8 \%$ - ethnic Russians.

\section{Conclusion}

By 1884, the system of public education in Elisabethpol Governorate was still in its incipience. Given the region's idiosyncrasies, girls had access to primary education only. The total number of educational institutions in the region was 39, with 2 of these being secondary, 4 - lower, and 33 - primary schools. The region had just two primary schools for girls. Its two other primary educational institutions were mixed schools. The rest of the region's educational institutions were for boys only. The total number of students in the region at the time was 2,789-2,492 boys and 297 girls. Over $57 \%$ of the student body was made up of Armenians (1,606 students), followed by Tatars - $23 \%$, Europeans - $13.8 \%$, and ethnic Russians - less than $5 \%$.

\section{References}

Magsumov et al., 2018 - Magsumov, T.A., Artemova, S.F., Balanyuk, L.L. (2018). Regional problems of public schools in the Russian Empire in 1869-1878 (using an example of the Vyatka Province). European Journal of Contemporary Education. 7(2): 420-427.

Magsumov et al., 2020 - Magsumov, T.A., Korolev, A.A., Ponomareva, M.A., Zulfugarzade, T.E. (2020). The System of Public Education in Kars Oblast in the Period 18781917. Part 1. European Journal of Contemporary Education. 9(1): 221-234.

Magsumov et al., 2020a - Magsumov, T.A., Korolev, A.A., Ponomareva, M.A., Zulfugarzade, T.E. (2020). The System of Public Education in Kars Oblast in the Period 18781917. Part 2. European Journal of Contemporary Education. 9(2): 459-472.

Mamadaliev et al., 2020 - Mamadaliev, A.M., Karpukhin, D.V., Svechnikova, N.V., Médico, A. (2020). The System of Public Education in Tiflis Governorate in the Period 1802-1917. Part 1. European Journal of Contemporary Education. 9(1): 235-247.

Mamadaliev et al., 2020a - Mamadaliev, A.M., Karpukhin, D.V., Svechnikova, N.V., Médico, A. (2020). The System of Public Education in Tiflis Governorate in the Period 1802-1917. Part 2. Bylye Gody. 56(2): 530-540.

Mamadaliev et al., 2020b - Mamadaliev, A.M., Karpukhin, D.V., Svechnikova, N.V., Médico, A. (2020). The System of Public Education in Tiflis Governorate in the Period 1802-1917. Part 3. Bylye Gody. 57(3): 1065-1084.

Mamadaliev et al., 2020c - Mamadaliev, A.M., Karpukhin, D.V., Svechnikova, N.V., Médico, A. (2020). The System of Public Education in Tiflis Governorate in the Period 1802-1917. Part 4. Bylye Gody. 58(4): 2409-2426. 
Natolochnaya et al., 2018 - Natolochnaya, O.V., Miku, N.V., Zulfugarzade, T.E., Médico, A. (2018). Highland schools in the Caucasus: Historical background. European Journal of Contemporary Education. 7(3): 608-614.

Natolochnaya et al., 2019 - Natolochnaya, O.V., Bulgarova, B.A., Denisenko, V.N., Volkov, A.N. (2019). The History of the Public Education System in Vilna Governorate (the Second Half of the 19th and Early 20th Centuries). Part 1. European Journal of Contemporary Education. 8(3): 655-664.

Natolochnaya et al., 2019a - Natolochnaya O.V., Bulgarova B.A., Voropaeva Yu.A., Volkov A.N. (2019). The History of the Public Education System in Vilna Governorate (the Second Half of the 19th and Early 20th Centuries). Part 2. European Journal of Contemporary Education. 8(4): 964-972.

Natolochnaya et al., 2020 - Natolochnaya, O.V., Svechnikov, V.A., Posokhova, L.A., Allalyev, R.M. (2020). The History of the Public Education System in Vilna Governorate (the Second Half of the 19th and Early 2oth Centuries). Part 3. European Journal of Contemporary Education. 9(1): 248-254.

Otchet, 1885 - Otchet popechitelya Kavkazskogo uchebnogo okruga o sostoyanii uchebnykh zavedenii za $1884 \mathrm{~g}$. [Report of the trustee of the Caucasian educational district on the state of educational institutions for 1884]. Tiflis, 1885. [in Russian]

Peretyatko, Zulfugarzade, 2017 - Peretyatko, A.Y., Zulfugarzade, T.E. (2017). Project of reforms proposed for the don public education in the first half of 1860: A.M. Dondukov-Korsakov, Kh.I. Popov, N.I. Krasnov. European Journal of Contemporary Education. 6(4): 817-829.

Peretyatko, Zulfugarzade, 2017a - Peretyatko, A.Y., Zulfugarzade, T.E. (2017). Higher and secondary education of the don cossacks in the context of the epoch: The time of the great reforms. European Journal of Contemporary Education. 6(2): 367-377.

Peretyatko, Zulfugarzade, 2019 - Peretyatko, A.Y., Zulfugarzade, T.E. (2019). «66 \% of Literacy among the Male Population of School Age Brings it Closer to Common Education» vs «in the Largest Villages, it was Difficult to Meet a Literate Person»: the Main Statistical indicators of Primary Education among Don Cossacks in the XIX c. Part 1. European Journal of Contemporary Education. 8(2): 454-465.

Peretyatko, Zulfugarzade, 2019a - Peretyatko, A.Y., Zulfugarzade, T.E. (2019). «66 \% of Literacy among the Male Population of School Age Brings it Closer to Common Education» vs «in the Largest Villages, it was Difficult to Meet a Literate Person»: the Main Statistical indicators of Primary Education among Don Cossacks in the XIX c. Part 2. European Journal of Contemporary Education. 8(3): 664-676.

Pervaya vserossiiskaya perepis'..., 1904 - Pervaya vserossiiskaya perepis' naseleniya Rossiiskoi imperii, $1897 \mathrm{~g}$. [The first all-Russian census of the population of the Russian Empire, 1897]. LXIII. Elisavetpol'skaya guberniya. SPb., 1904. [in Russian] 